\title{
PENINGKATAN PERKEMBANGAN KOGNITIF MELALUI PERMAINAN BALOK GEOMETRI PADA ANAK USIA 3-4 TAHUN DI PPT MAWAR O1 AR-RACHMAN SURABAYA
}

\author{
Masruroh \\ PPT MAWAR 01 AR-RACHMAN, Surabaya \\ Masruroh151266@gmail.com
}

\begin{abstract}
ABSTRAK
Salah satu kendala yang ditemukan peneliti di PPT Mawar 01 adalah kurangnya pemahaman kognitif anak dalam mengenal bentuk geometri dan membedakan ukuran yang sejenis.Untuk mengatasi hal tersebut peneliti berusaha memberikan pembelajaranmelalui media balok geometri yang dapat menjadi salah satu alternatif menarik sebagai media pembelajaran.Hasil penelitian dengan menggunakan metode Penelitian Tindakan Kelas (PTK) menunjukkan adanya peningkatan secara bertahap pada kemampuan anak dalam mengenal bentuk geometri.Peningkatan kemampuan mengenal bentuk geometri terlihat dari indikator kemampuan mengetahui, memahami, dan menerapkan bentuk geometri dalam bermain.Sebelum diberikan tindakan, nilai rata-rata kelas sebesar 33\%. Setelahpemberian tindakan melalui pembelajaran dengan menerapkan permainan balok pada Siklus I nilai rata-ratakelas meningkat menjadi $60 \%$ dan pada Siklus II nilai rata-rata kelas semakin meningkat hingga $87 \%$ sehingga mencapai angka indikator keberhasilan yakni $75 \%$. Hal ini menunjukkan bahwapembelajaran dengan menggunakan permainan balok geometri warna dapat meningkatkan perkembangan kognitif anak usia dini pada materi mengenal bentuk-bentuk geometri.
\end{abstract}

Kata Kunci: Balok Geometri, Media Pembelajaran, Perkembangan Kognitif

\begin{abstract}
One of the obstacles that researchers encountered in PPT Mawar 01 is the lack of understanding of the child's cognitive to recognize geometric shapes and distinguish similar size. Researcher overcome this problem through the geometry beam game as it can be one attractive alternative as a learning medium. Result of the research using ClassAction Research indicates a gradual improvement in children's ability to recognize geometric shapes. Increased ability to know the geometric shapes seen on the indicator of the ability to know, understand, and apply the geometric shapes in play. Before the given action, the value of the average grade of $33 \%$. After giving the action through learning by applying beam game in Cycle I value the class average increased to $60 \%$ and in Cycle II class average value increased by $87 \%$ to reach the $75 \%$ indicator of success. Its showed that learning with games beam geometry of color can enhance early childhood cognitive development on material familiar geometric shapes.
\end{abstract}

Keywords: geometry beam, medium of learning, cognitive development 


\section{PENDAHULUAN}

Pendidikan anak usia dini merupakan pendidikannon formal yang bertujuan untuk mengembangkan aspek perkembangan anak yang meliputi aspek kognitif, fisik, motorik, soaial emosional, agama serta perkembangan Bahasa.Adapun teori tahap perkembangan kognitif Piaget adalah : (1) Tahap Sensomotoris ( usia 0 - 2tahun ), (2) Tahap Praoperasional (usia $2-7$ tahun), (3) Tahap Konkrit Operasional (usia 7 - 11 tahun), (4) Tahap Operasional formal (usia 11 tahun - keatas). Anak usia dini yang berusia 2 hingga 7 tahun berada pada tahapan Praoperasional. Di mana anak mampu berfikir tentang obyek benda, kejadian, atau orang lain. Anak sudah mulai mengenal simbol berupakata-kata, angka,gambar dan gerak tubuh. Namun cara berfikir ini masih tergantung pada obyek konkrit dan rentang waktu kekinian, serta tempat di mana ia berada. Mereka belum mampu berfikir abstrak sehingga simbol-simbol yang konkrit sangat dibutuhkan untuk dapat dipahami mereka.Misalnya dalam mengenalkan bentuk geometri dengan obyek nyata berupa gambar atau balok.

Perkembangan Kognitif pada anak usia 3-4 tahun menurutPeraturan Menteri No. 137 tahun 2014 adalah anak mampu menempatkan benda dari urutan ukuran paling kecil sampai yang paling besar;mampu mengurutkan angka 1-10;mampu membedakan warna, merah, hijau, kuning, hitam dll; mengenal konsep banyak/sedikit;dan menggambar atau membentuk kontruksi dengan mendeskripsikan sesuatu yang spesifik. Media balok merupakan potongan kayu yang memiliki berbagai bentuk.Umumnya berbentuk segi empat atau kubus.Perkembangannya,balok sebagai alat permainan tidak hanya dibuat dari kayu, melainkan dari berbagai bahan seperti, karton, busa, karet, dan sebagainya. Anak-anak suka menumpuk balok atau menggabungkan balok untuk memuaskan imajinasinya akan sebuah bentuk. Beberapa jenis balok yang dipergunakan sebagai alat permaianan antara lain adalah balok unit, balok besar, balok berongga, balok lego dan balok lainnya.Adapun keuntungan permainan balokyaitu :1) menstimulasi mental, 2) membangun kreativitas, 3) membangun kemampuan motorik. 4) melatih kesabaran, 5) melatih daya ingat berbahasa dan berhitung, 6) serta meningkatkan interaksi sosial.

Menurut Sujiono dkk (2006 : 2.17) kemampuan ini berhubungan dengan pengembangan konsep bentuk dan ukuran. Adapun kemampuan yang akan dikembangkan, antara lain: Memilih benda menurut warna bentuk dan ukurannya, Mencocokkan benda menurut bentuk, warna, dan ukurannya, Membandingkan benda menurut ukurannya besar, kecil, panjang, lebar, tinggi, rendah, menyebutkan benda-benda yang ada di kelas sesuai dengan bentuk geometri, Mencontoh bentuk-bentuk geometri, menyebutkan menujukkan dan mengelompokkan segi empat.

Hubungan media balok dengan kognitif sangat erat kaitannya dikarenakan pembelajaran dengan menggunakan media balok anak mampu mengingat dan berpikir dari pengalaman- pengalaman yang dialaminya serta mampu mengenal ukuran, warna dan berbagai bentuk. Dari kegiatan-kegiatan yang anak alami dalam bermain dengan menggunakan media balok anak akan mengenal ukuran, bentuk, warna sehingga akan mudah tercapai perkembangan kognitif anak usia dini.

Dalam proses pembelajaran anak usia dini guru harus menggunakan berbagai media yang menarik bagi anak, salah satunya seperti media permainan balok, dengan balok tersebut anak akan merasa senang sehingga mereka menyenangi kegiatan yang diberikan oleh gurunya. Hal ini akan meningkatkan dorongan atau motivasi anak untuk bermain sambil belajar sehingga pada akhirnya mereka dapat menguasai konsep bentuk, 
ukuran, warna dan lain-lain. Dengan demikian akan terjadi peningkatan kemampuan kognitif anak untuk mengingat berbagai konsep bentuk, ukuran dan warna.

Dapat dipahami bahwa sangat erat hubungannya antara media balok dengan pembentukan perkembangan kognitif anak usia dini, dikarenakan dengan anak belajar sambil bermain menggunakan balok, maka anak akan mudah mengenal hal-hal yang berkaitan dengan kehidupannya sehari-hari, contohnya pada saat anakbermain balok anak akan mengenal warna, bentuk dan berbagai macam ukuran.

Adapun permasalahan yang terjadi pada kelompok B di PPT Mawar 01 Ar-Rachman Surabaya dalam kemampuan mengenal bentuk geometri masih rendah. Rendahnya kemmpuan tersebut dikarenakan :1) Peserta didik di kelompok B belum mampu mengenali bentuk geometri (segitiga, lingkaran, segi empat, persegi panjang) berdasarkan bentuk dan ukurannya. 2) Peserta didik belum mampu mengklasifikasikan benda ke dalam kelompok berpasangan dengan 2 variasi atau yang sejenis. 3) Pendidik belum memanfaatkan media pembelajaran yang ada untuk diperlihatkan secara langsung kepada peserta didik.

Merujuk pada beberapa paparan di atas, maka perlu adanya Stimulasi pada anak Usia 3-4 tahun di PPT Mawar 01 Ar-Rachman Surabaya, Untuk meningkatkatkan perkembangan kognitifnya melalui bermain Balok Geometri, yang mana pada saat ini siswa/siswi PPT Mawar 01 Ar-Rachman Surabaya dalam mengenal bentuk geometri perlu mendapatkan Stimulus yang optimal. Adapun pembelajaran yang akan dikenalkan dalam bermain Balok Geometriadalah : 1) Mengenal dan mengetahui bentuk geometri 2) Mampu membedakan bentuk geometri (segi tiga, lingkaran, persegi panjang, segi empat), 3) Mampu menyebutkan bentuk geometri (segi tiga, lingkaran, persegi panjang, segi empat),4) Mengelompokkan benda sesuai bentuknya.

\section{METODE PENELITIAN}

Metode yang digunakan dalam penelitian ini yaitu Peneltian Tindakan Kelas (PTK). Menurut Hopkirs (RochiatiWiriaatmaja, 2005: 11) pengertian penelitian tindakan kelas adalah penelitian yang mengkombinasikan prosedur penelitian dengan tindakan subtansif, suatu tindakan yang dilakukan dalam disiplin inkuiri, atau usaha seseorang untuk memahami apa yang sedang terjadi sambil terlibat dalam sebuah peoses perbaikan dan perubahan.

Model Kemmis dan Mc Taggart dalam Arikunto (2006:97), alur penelitian itu terdiri dari empat kegiatan pokok, yaitu perencanaan (planning), pelaksanaan (acting), pengamatan (observing) dan refleksi (reflecting). Antara tindakan (acting) dan pengamatan (observing) sebagai satu kesatuan yang saling terkait. Hasil dari tindakan dan pengamatan dijadikan dasar untuk mencermati apa yang sudah terjadi (reflecting).

Adapun proses pelaksanaan penelitian tindakan kelas ini sebagai berikut:1) Perencanaan (planning). Kegiatan yang dilaksanakan pada tahap inidiantaranya: a) Penyusunan rencana yang di awali dengan observasi mengenai kemampuan peserta didik dalam mengenal bentuk geomatri melalui media balok geometri. b) Merumuskan rencana tindakan yang akan dilakukan, dengan mempertimbangkan keadaan dan suasana objektif dan subjektif;2) Pelaksanaan (acting) dan pengamatan (observing). Pada tahap pelaksanaan, guru melaksanakan kegiatan pembelajaran melalui media balok geometri untuk meningkatkan kognitif anak dalam mengenal konsep bentuk geometri dengan rencana yang dibuat saat tahap perencanaan.Pada tahap pengamatan, peneliti mengamati 
jalannya kegiatan pembelajaran di kelas yang sedang berlangsung.Untuk mendapatkan data yang diperlukan dalam penerapan pendekatan; 3) Refleksi (reflecting).Data yang diperoleh dari pelaksanaan dan pengamatan dikumpulkan dan dianalisis sehingga diperoleh kesimpulan tentang berhasil atau tidaknya kegiatan pembelajaran yang dilaksanakan dengan penerapan pembelajaran melalui media balok geometri.Kekurangan, kelebihan, dan hasil yang diperoleh pada siklus 1 ini dijadikan acuan untuk melakukan perbaikan pada siklus II.

Sebelum mengadakan penelitian lebih lanjut, peneliti mengadakan observasi yang disebut dengan Pratindakan sebelum Siklus I dan Siklis II.Pada Pratindakan ini peneliti menggunakan media pembelajaran dengan menggunakan media gambar diatas kertas dengan tema rumah untuk mengenalkan bentuk geometri pada anak, namun media ini hasilnya kurang optimal, karena menggunakan media gambar diatas kertas sangat monoton. Berangkat dari sini peneliti mencoba mencari media pembelajaran yang tepat yang dapat di gunakan untuk anak usia3-4 tahun yaitu dengan menggunakan media balok geometri berwarna.

Setelah dilakukan penelitian dengan menggunakan media balok geometri diperolehlah hasilnya. Berdasarkan hasil Pratindakan, Siklus I dan Siklus II yang telah dilakukan oleh peneliti, maka diperoleh data kemampuan kognitif anak PPT Mawar 01 ArRachman Surabaya.

Untuk mengetahui berhasil atau tidaknya dalam meningkatkan perkembangan kognitif anak dilakukan analisis persentase, dengan rumus sebagai berikut :

$$
\mathrm{P}=\frac{f}{N} \times 100 \%
$$

Keterangan :

$\mathrm{f}$ : Frekuensi yang sedang dicari

presentasenya.

$\mathrm{N}$ : Jumlah Frekuensi

P : Angka persentase (Purwanto Ngalim, 2009).

\section{HASIL DAN DISKUSI}

Dalam penelitian tindakan kelas yang dilakukan untuk meningkatkan perkembangan kognitif anak usia 3-4 tahun di PPT Mawar 01 Ar-Rachman Surabaya tahun ajaran 2018/2019 peneliti menggunakan 2 siklus dalam pembelajaran dengan mengamati 21 anak yang dibagi kedalam 2 kelompok. Pada setiap siklus terjadi 3 kali pertemuan pembelajaran.

\section{Hasil Observasi Pratindakan}

Kegiatan awal yang dilakukan oleh peneliti sebelum pelaksanaan tindakan penelitian adalah mengetahui kondisi awal anak dengan melakukan observasi awal atau pra tindakan. Kegiatan pra tindakan dilakukan pada bulan 4 Februari 2019. Hal yang diamati dalam pra tindakan ini adalah kemampuan mengenal bentuk geometri pada anak kelompok B. Pada kegiatan pratindakan, tema pembelajaran adalah Rumah. Peneliti hanya memfokuskan pengamatan pada kemampuan mengenal bentuk geometri. 
Hasil pengamatan yang dilakukan oleh peneliti yaitu, guru dalam mengajarkan mengenal bentuk-bentuk geometri menggunakan media gambar. Guru mengajak anak untuk bersama-sama menyebutkan bentuk geometri apa yang ada pada gambar rumah. Anak terlihat bosan dan guru tidak dapat mengetahui pasti apakah semua anak mengetahui bentuk geometri yang dipegang oleh guru atau hanya ikut temannya. Hal tersebut terlihat pada saat anak menyebutkan bentuk geometri sambil melihat temannya tidak melihat bentuk geometri yang dipegang oleh guru. Dari observasi diatas kemampuan anak kurang maksimal.

Hasil observasi kemampuan kognitif anak dalam mengenal bentuk geometri pada pratindakan anak usia 3 - 4 tahun di PPT Mawar 01 Ar-Rachman Surabaya yang dilakukan pada tanggal 4 Februari 2019 dengan media awal yang digunakan media gambar diatas kertas menunjukkan hasil sesuai grafik dibawah ini :

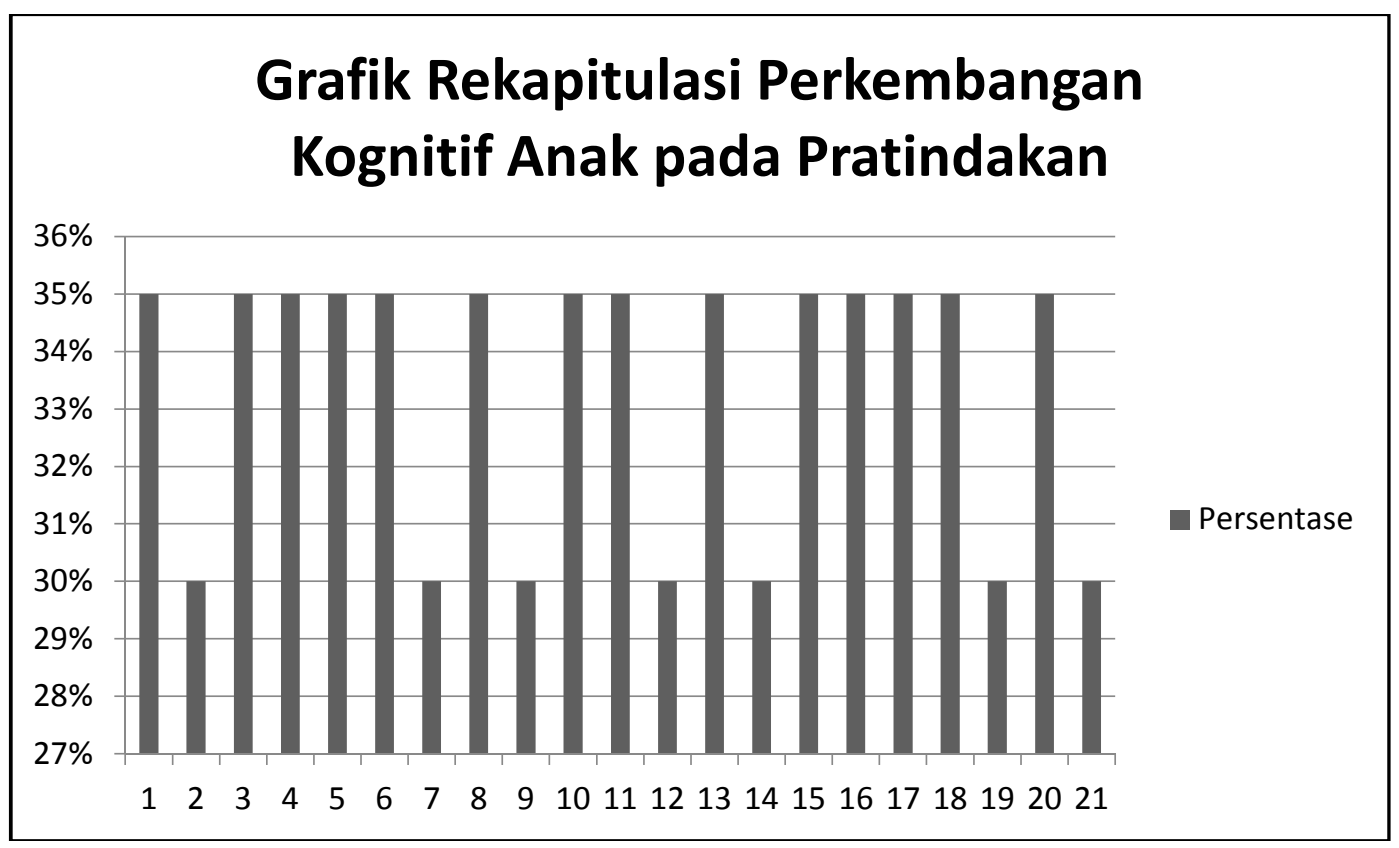

\section{Gambar 4.1 Grafik Rekapitulasi Pemerolehan Skor Perkembangan Kognitif Pratindakan}

Hasil observasi pada tanggal 04 Februari 2019 pada anak usia 3-4 tahun di PPT Mawar 01 Ar-Rachman Surabaya, menyebutkan bahwa dari 21 responden, kemampuan anak dalam mengenal kelima butir instrument menunjukkan mulai berkembang (MB) dengan menunjukkan capaian rata-rata kelas sejumlah $33 \%$ dan belum mencapai kriteria yang ditentukan sebesar $75 \%$.

Berdasarkan data yang sudah diperoleh dari lembar observasi yang kemudian dijadikan grafik dapat diketahui bahwa pada pratindakan kemampuan kognitif anak dalam materi mengenal bentuk geometri melalui media gambar diatas kertas masih kurang optimal. Hal ini yang menjadi landasan peneliti untuk meningkatkan perkembangan kognitif anak usia 3-4 tahun di PPT Mawar 01 Ar-Rachman Surabaya. 


\section{Siklus I}

Pelaksanaan Siklus I dilaksanakan sebanyak tiga kali pertemuan yaitu pada hari selasa tanggal 12 Februari 2019, Kamis tanggal 14 Februari 2019, dan Sabtu tanggal 16 Februari 2019, Setiap pertemuan anak akan dikenalkan bentuk geometri melalui permainan balok yang sudah di sediakan. Adapun hasil dari Siklus I dapat dilihat pada grafik dibawah ini :

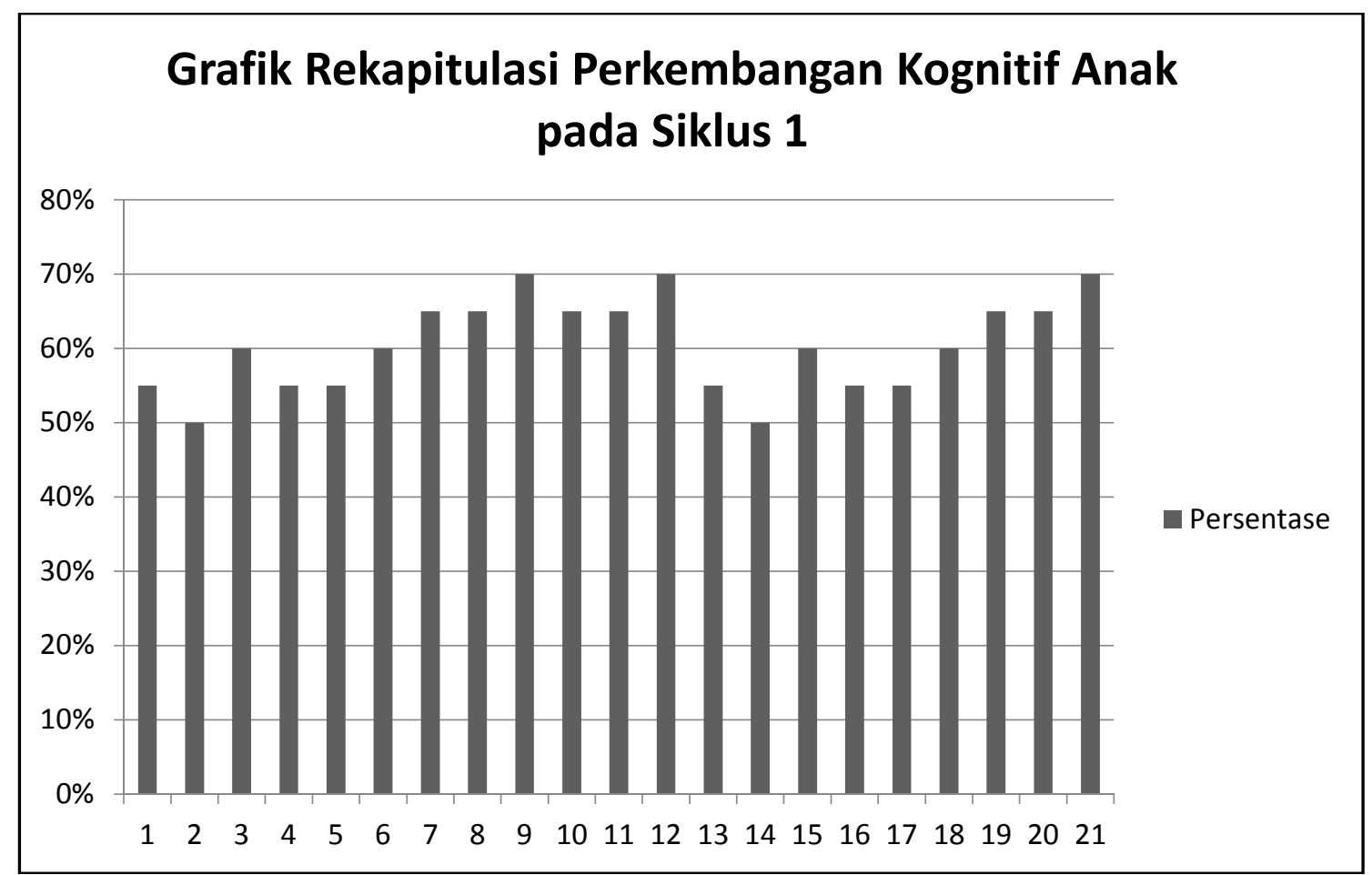

\section{Gambar 4.2Grafik Rekapitulasi Data Kemampuan Kognitif Anak Pada Siklus I}

Berdasarkan grafik diatas dapat dilihat bahwa kemampuan kognitif pada anak usia 3-4 tahun di PPT Mawar 01 Ar-Rachman Surabaya dari 21 anak responden dalam mengenali lima butir instrument yang dikategorikan menunjukkan bahwa perkembangan anak berkembang sesuai harapan (BSH) dengan capaian rata-rata kelas sejumlah $60 \%$ dan belum mencapau kriteria yang diharapkan sebesar $75 \%$. Sehinggal masih perlu dilakukan tindakan perbaikan pada siklus II. Adapun permasalahan yang muncul selama proses pembelajaran berlangsung adalah sebagai berikut: 1) Anak masih bingung dengan materi geometri yang tidak pernah dikenalkan guru secara khusus sebelumnya. 2) Anak masih suka bercerita dan mengganggu teman saat proses kegiatan berlangsung. 3) Anak masih suka berebut balok yang diberikan guru sehingga ada yang bertengkar lalu tidak mau ikut kegiatan. 4) Kurangnya pemberian motivasi dan penguatan kepada anak saat proses pembelajaran berlangsung.

\section{Siklus II}


Pada pelaksanaan penelitian tindakan Siklus II peneliti berkolaborasi dengan guru. Tugas peneliti adalah mengamati, menilai, danmendokumentasikan kegiatan anak ketika sedang melakukan permainan balok. Tugas guru yakni melaksanakan kegiatan belajar mengajar dengan Rencana Pelaksanaan Pembelajaran Harian (RPPH) yang disusun bersama guru. Sebelum dilaksanakan kegiatan pada Siklus II seperti biasa guru melaksanakan kegiatan prapengembangan seperti penyiapan alat dan bahan sebelum kegiatan pembelajaran Siklus II.

Pertemuan pertama Siklus II dilaksanakan pada hari Selasa tanggal 19 Februari 2019, Kamis tanggal 21 Februari 2019, Sabtu tanggal 23 Februari 2019. Tema yang diangkat kota Surabaya dengan sub tema jalan-jalan kemol.Pada siklus II ini, anak-anak mulai mengetahui aturan apa yang diberikan guru sebelum kegiatan pembelajaran di mulai. Anak mampu menceritakan setiap hasil karya yang di buat nya sendiri. Dan antusias anak bisa mengikuti kegiatan dari awal sampai akhir. Observasi dilaksanakan saat proses pembelajaran berlangsung, terutama setelah anak-anak selesai melaksanakan kegiatan bermain dengan mencetak dalam bentuk geometri yang sudah di sediakan oleh guru. Dari 21 anak yang sudah mengikuti bisa mengikuti kegiatan bermain balok dengan rancangan yang dibuat oleh guru dan peneliti. Mulai dari mengenal bentuk- bentuk geometri lingkaran, segitiga, segiempat sudah baik. Antusias anak terlihat pada Siklus II karena anak sudah mulai memahami peraturan dalam kegiatan pembelajaran melalui bermain tersebut, dengan perasaan senang dan antusias. Sebelum kegiatan berlangsung, guru terlebih dahulu mengajak anak untuk menyebutkan bentuk-bentuk geometri apa saja yang sudah kita pelajari, selanjutnya guru memberitahukan mengenai tugas yang akan dikerjakan oleh anak. Anak-anak tampak senang karena sebelumnya pada Siklus I anak sudah mengalami kegiatan pemberian tugas, sehingga pada siklus II anak sudah paham. Hampir semua anak yang terdiri dari 2 kelompok tersebut mampu menunjukan kemampuan lima indikator yang di harapkan oleh penulis yaitu mampu mengurutkan benda dari ukuran yang paling kecil sampai yang paling besar, anak mampu membedakan warna, anak mampu mengenal konsep banyak atau sedikit, anak mampu membuat bangunan kontruksi kecil, anak mengenal bentuk geometri.

Hasil observasi menunjukan bahwa kegiatan pembelajaran telah dilaksanakan sesuai dengan Rencana Pelaksanan Pembelajaran Harian (RPPH). Pada akhir pembelajaran telah diadakan evaluasi untuk mengetahui peningkatan kemampuan kognitif pada materi mengenal bentuk-bentuk geometri. 


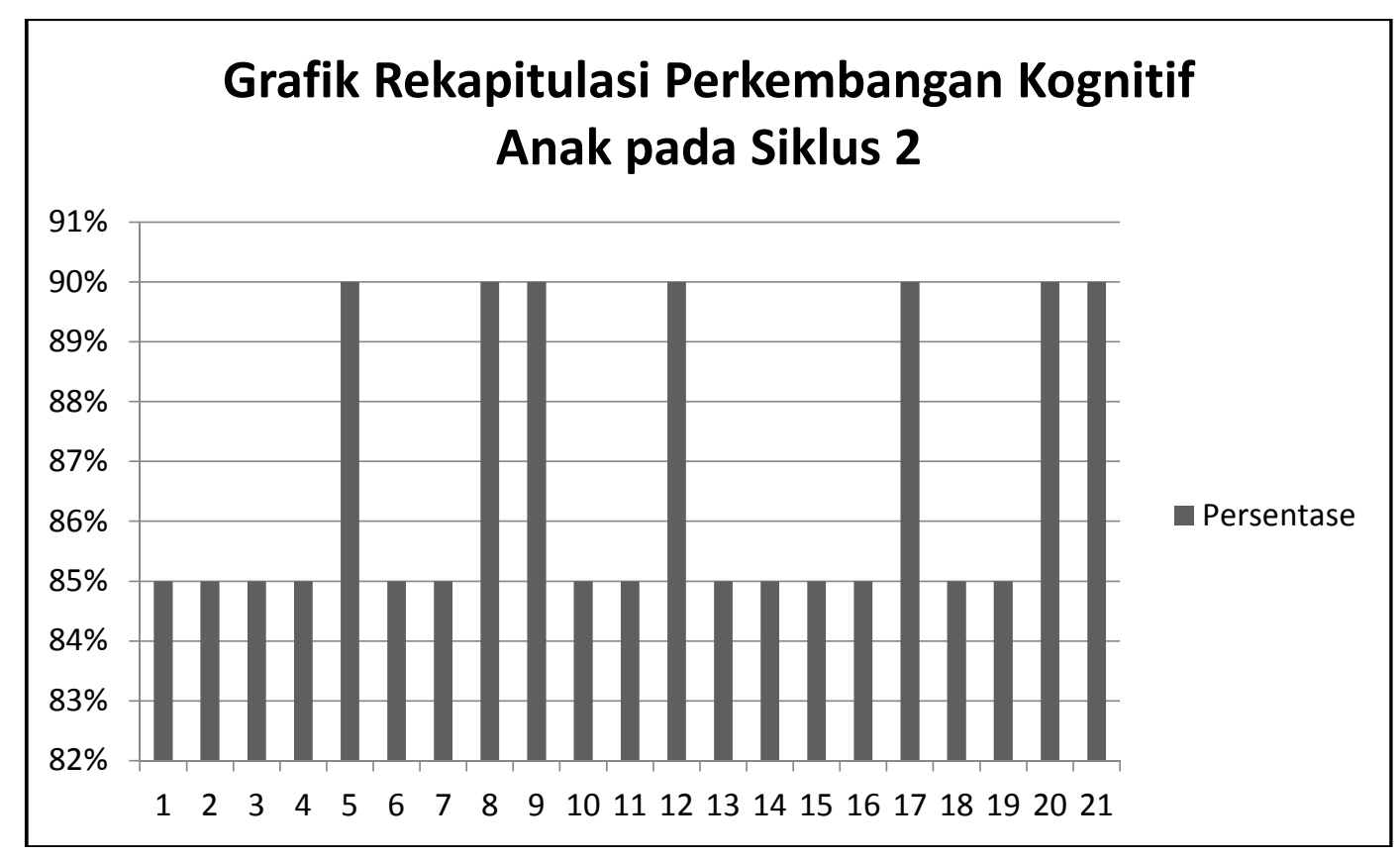

\section{Gambar 4.3 Grafik Rekapitulasi data kognitif anak pada Siklus II}

Berdasarkan grafik diatas dapat dilihat adanya kemajuan yang baik sekali anak dalam mengenal geometri dalam permainan balok. Hal ini dibuktikan dengan hasil observasi setiap anak rata-rata $87 \%$ dari seluruhnya dan sudah memenuhi target yang di harapkan yaitu $75 \%$ Selama proses tindakan Siklus II dengan menerapkan media pembelajaran melalui permainan balok, penulis masih tetap meminta bantuan guru inti untuk melakukan pengamatan terhadap kegiatan pembelajaran yang dilakukan penulis selama mengadakan penelitian. Pembelajaran pada Siklus II telah diadakan perbaikan-perbaikan untuk mencapai indikator. Perbaikan tersebut antara lain, pemberian balok warna pada tiap-tiap anak, adanya pemberian pengarahan kepada anak-anak melalui instruksi agar anak dapat melakukan kegiatan pembelajaran bermain balok dengan baik dan benar. Melalui perbaikan tersebut pembelajaran pada siklus II mencapai indikator yang di tentukan.

Berdasarkan hasil diatas terbukti bahwa dengan menerapkan pembelajaran dengan permainan balok dalam bentuk geometri dapat meningkatkan perkembangan kemampuan kognitif anak usia 3-4 tahun di PPT Mawar 01 ar-Rachman Surabaya. 


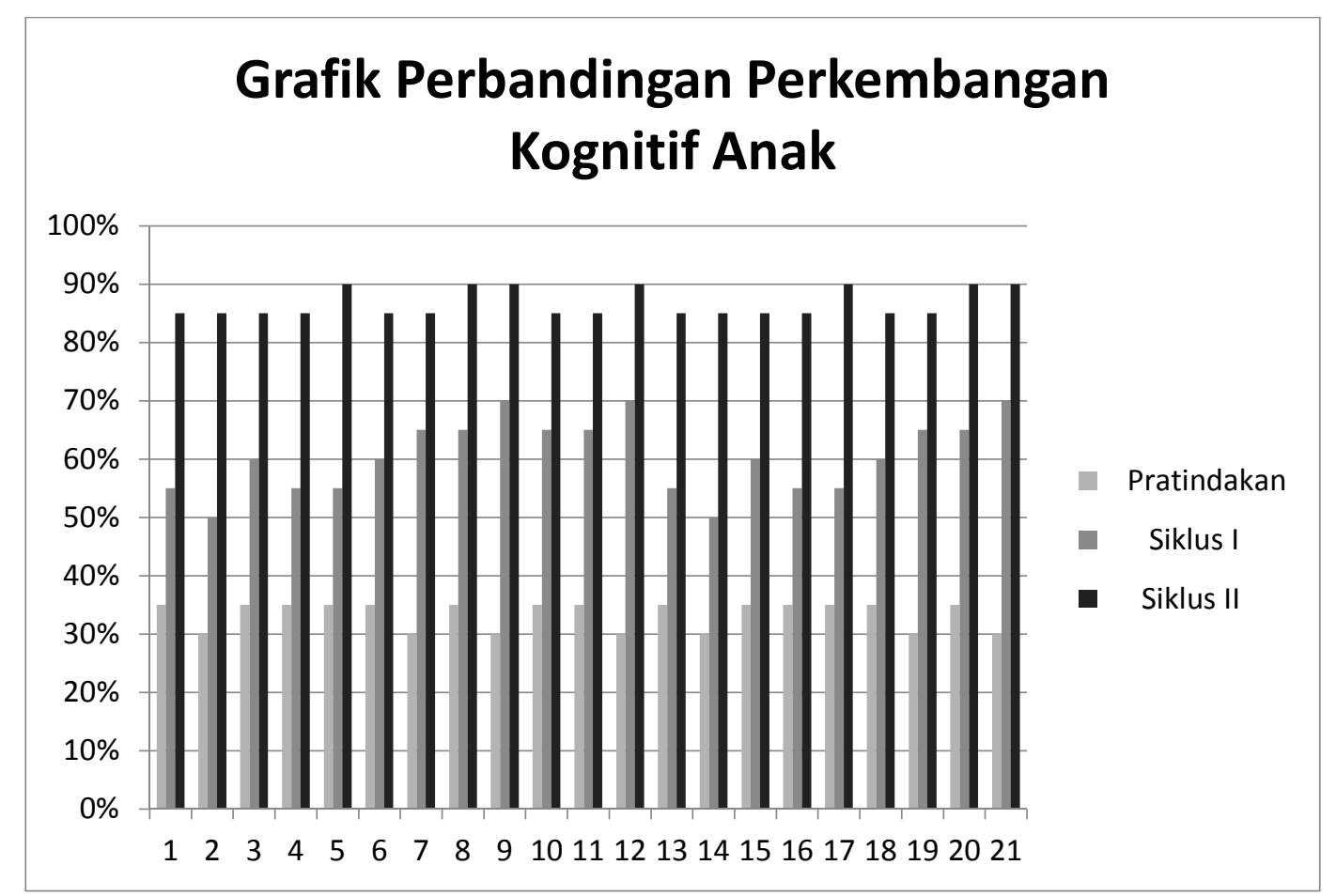

\section{Gambar 4.4 Grafik Rekapitulasi perbandingan Skor}

Berdasarkan hasil penelitian dapat disimpulkan bahwa penerapan media balok geometri dapat meningkatkan perkembangan kognitif anak usia 3-4 tahun di PPT Mawar 01 Ar-Rachman Surabaya. Hasil penelitian sebelum diberikan tindakan, sebesar 33\% Setelah pemberian tindakan melalui pembelajaran dengan menerapkan model pembelajaran pada Siklus I nilai rata-rata kelas meningkat $60 \%$. Pada Siklus II nilai rata-rata kelas semakin meningkat hingga mencapai $87 \% . \mathrm{Hal}$ ini berarti pembelajaran dengan menggunakan permainan balok warna dapat meningkatkan perkembangan kognitif anak usia dini pada materi mengenal bentuk-bentuk geometri.

Adapun untuk memenuhi tingkat keberhasilan anak, peneliti mengupayakan untuk memenuhi kekurangan-kekurangan yang ada pada Siklus I dan Siklus II misalnya, peneliti menstimulasi anak agar terangsang untuk melakukan kegiatan belajar dan bermain baik dengan lagu maupun permainan. Guru melakukan tindakan pada Siklus II yang tidak dilakukan pada Siklus I, misalnya memberikan beberapa balok geometri kepada tiap-tiap anak agar anak tidak rebutan dan lebih kondusif saat tindakan dan pembelajaran di dalam kelas maupun di luar kelas berlangsung.

Hurlock (2011: 50) menyatakan bahwa anak usia 3-5 tahun adalah masa bermain. Bermain dengan benda atau alat, permainan dimulai sejak usia satu tahun pertama dan mencapai puncaknya pada usia 5-6 tahun. Menurut Piaget, usia 5-6 tahun ini merupakan pra operasional konkret. Pada tahap ini anak memanipulasi objek simbol, termasuk kata-kata yang merupakan karateristik penting dalam tahapan ini. Hal ini dinyatakan dalam peniruan yang tertunda dan dalam imajinasi pura-pura dalam bermain. 


\section{KESIMPULAN}

Permainan balok dalam bentuk geometri dapat meningkatkan perkembangan kognitif pada anak usia 3 - 4 tahun dengan materi mengenal bentuk - bentuk geometri dan membedakan ukuran yang sejenis di PPT Mawar 01 Ar-Rachman Surabaya. Hasil pengamatanmenunjukkan persentase awal saat pratindakan 33\%, setelah pelaksanan pada siklus I, 60\% dan ketuntasan meningkat di Siklus II menjadi $87 \%$ sehingga mencapai dari indikator keberhasilan 75\%.Dengan demikian dapat disimpulkan bahwa permainan balok dalam bentuk geometri dapat meningkatkan perkembangan kognitif anak usia 3-4 tahun di PPT Mawar 01 Ar-Rachman Surabaya.

\section{DAFTAR PUSTAKA}

Hurlock 2011, Hurlock, B. 1997. Perkembangan Anak Jilid I.Jakarta: Erlangga.

Peraturan Menteri Pendidikan dan Kebudayaan Republik Indonesia Nomor 137 Tahun 2014 tentang Standar Nasional Pendidikan Anak Usia Dini.Jakarta

Purwanto,Ngalim. 2009. Evaluasi Hasil Belajar. Yogyakarta : Pustaka Pelajar

Sujiono, Y. 2007. Perkembangan anak. Jakarta. Erlangga 